\title{
Impact of hypertension in liver regeneration in rats $^{1}$
}

\author{
Repercussão da hipertensão arterial na regeneração hepática em ratos
}

\author{
Maria de Lourdes Pessole Biondo-Simões ${ }^{\mathrm{I}}$, Camila Gadens ZamboniI ${ }^{\mathrm{II}}$ Evelise Martins ${ }^{\mathrm{II}}$, Luka David Lechinewski ${ }^{\mathrm{II}}$, Sérgio \\ Ossamu Ioshii' ${ }^{\text {III }}$, Rogerio Ribeiro Robes ${ }^{\text {IV }}$ \\ ${ }^{\mathrm{I}} \mathrm{PhD}$, Full Professor, Scientific Methodology, Catholic University of Parana (PUCPR) and Associate Professor, Department of Surgery, UFPR, Parana, \\ Brazil. Concept, design, acquisition, analysis and interpretation of data; critical review of the study. \\ IIGraduate student, Scientific Initiation Program, UFPR, Parana, Brazil. Acquisition of data and drafting of the article. \\ IIIPhD, Associate Professor, Division of Pathology, PUCPR and Associate Professor, Division of Pathology, UFPR, Parana, Brazil. Pathology data \\ interpretation. \\ ${ }^{\mathrm{IV}}$ Master, Full Professor, Anesthesiology, Faculty of Veterinary Medicine, UFPR, Parana, Brazil. Involved with technical procedures and acquisition \\ of data.
}

\begin{abstract}
PURPOSE: To determine the impact of hypertension in liver regeneration, in rats by examining gain in liver mass and the replication of hepatocytes and stellate cells.

METHODS: Forty Wistar rats were allocated into two groups of twenty, the control and experiment group. The experiment group animals were submitted to induction of renovascular hypertension. A week later, all the animals underwent a partial hepatectomy. Measurements were taken after 24 hours and seven days, when ten animals in each group were euthanized. Thus, four subgroups were obtained. The livers were excised and sent for histopathological analysis.

RESULTS: The control group had a greater gain in liver mass than the experiment group seven days after partial hepatectomy ( $\mathrm{p}=0.0051$ ). The difference in the activate stellate cell count was not statistically significant following analysis after both 24 hours and seven days $(p=1.0)$. A higher number of dividing hepatocytes was observed in the control group seven days after partial hepatectomy $(p=0.0014)$.

CONCLUSION: In rats, hypertension had no direct influence on stellate cell replication, but led to a delay in liver mass gain and were shown to be a reduction factor on hepatocyte replication seven7 days after partial hepatectomy.
\end{abstract}

Key words: Hypertension. Liver Regeneration. Rats.

\section{RESUMO}

OBJETIVO: Determinar o impacto da hipertensão arterial sistêmica na regeneração hepática, em ratos, através da análise do ganho de massa hepática e da replicação dos hepatócitos e das células estreladas.

MÉTODOS: Alocaram-se 40 ratos Wistar em dois grupos de 20 animais, os grupos controle e experimento. Os do grupo experimento submeteram-se a indução da hipertensão renovascular. Uma semana após, realizou-se hepatectomia parcial em todos os animais. Colheram-se os dados com 24 horas e sete dias, quando dez animais de cada grupo submeteram-se a eutanásia. Assim, obtiveram-se quatro subgrupos. Os fígados foram retirados e enviados para análise histopatológica.

RESULTADOS: O grupo controle apresentou maior ganho de massa hepática do que o grupo experimento sete dias após a hepatectomia parcial $(\mathrm{p}=0,0051)$. A diferença na contagem das células estreladas ativadas não foi estatisticamente significante nas análises de 24 horas e de sete dias $(\mathrm{p}=1,0)$. Um maior número de hepatócitos em divisão foi observado no grupo controle, sete dias após a hepatectomia parcial $(\mathrm{p}=0,0014)$.

CONCLUSÃO: Em ratos, a hipertensão não teve influência direta sobre a replicação de células estreladas, mas levou ao atraso no ganho de massa hepática e mostrou ser um fator de redução na replicação de hepatócitos sete dias após a hepatectomia parcial.

Descritores: Hipertensão. Regeneração Hepática. Ratos. 


\section{Introduction}

All liver cells (hepatocytes, endothelial cells, stellate cells, ductal and Kupffer cells) proliferate to replace the loss of hepatic tissue. However, hepatocytes are the first to proliferate and most studies highlight these cells because they constitute about $90 \%$ of hepatic mass and $60 \%$ of total cells ${ }^{1,2}$. The hepatocyte is an epithelial nature cell, stable, highly differentiated, which rarely divides $^{3}$.

Hepatic stellate cells reside in perisinusoidal Disse space, which is coated by hepatic parenchymal cells and endothelial cells of the fenestrated waveform. After the injury of the liver stellate, quiescent cells are activated and are converted into myofibroblastlike contractile cells, which secrete soluble factors and hepatic matrix molecules ${ }^{4}$. Although there is some evidence to support the participation of stellate cells in liver regeneration ${ }^{5}$, there are few data available on the activation and morphology of these cells in the regenerating liver ${ }^{6-8}$. It is hitherto unclear whether stellate cells are indispensable for regeneration ${ }^{9}$ or whether the products of activated stellate cells are needed to mitigate injury to the hepatocytes, enhance hepatocellular regeneration or both ${ }^{4}$. Nevertheless, the involvement of stellate cells in the process is widely accepted ${ }^{5}$.

The study of liver regeneration and factors that may accelerate or retard this process are highly relevant, to the extent that several authors have attempted to find agents that somehow contribute toward accelerating the regeneration process ${ }^{10}$.

Some authors have reported that although the angiotensin converting enzyme (ACE) involved in the pathogenesis of hypertension inhibits liver regeneration, the mechanisms through which this occurs remain unknown ${ }^{11,12}$. Increasingly, patients with comorbidities, including hypertension, are being submitted to surgery. It is necessary to recognize how and with what intensity factors intrinsic to the condition of each patient can influence regeneration and how growth factors can be used to improve liver regeneration.

The present study aims to investigate the impact of hypertension in liver regeneration after partial hepatectomy in rats by analyzing liver mass gain and replication of hepatocytes and stellate cells.

\section{Methods}

The research project from which this study originated was evaluated and approved by the Ethics Committee for Animal Research at Hospital de Clinicas, Federal University of Parana, under registration number AN.015.006.08.09. The research was conducted within the guidelines of the Brazilian College of Animal Experimentation (COBEA) and Federal Law N. ${ }^{\circ} 11.794$.

A total of 40 male Wistar rats (Rattus norvegicus albinos, Rodentia mammalia), aged 120 days and weighing 250 grams were kept in cages with a light-dark cycle, temperature and humidity own environment, with free access to water and commercial feed.

The sample was divided into two groups of 20 rats in order to constitute the control group (C) and experimental group (E). Under an anesthesia of $0.1 \mathrm{ml} / 100 \mathrm{~g}$ body weight of a mixture of $1 \mathrm{ml}$ of ketamine $(50 \mathrm{mg}$ ) and $1 \mathrm{ml}$ xylazine $(20 \mathrm{mg})$, the animals were subjected to digital waxing of the ventral abdominal wall and antisepsis with polyvinylpyrrolidone-iodine.

The animals then underwent a laparotomy and induction of vascular renovascular hypertension using the technique of Goldblatt (two kidneys and a clip). For this we used a catheter with a one millimeter diameter to carry out the ligation of the left renal artery, followed by catheter removal. This procedure assured a decrease in arterial lumen without inducing ischemia of the kidney. After laparorrhaphy the animals were returned to their boxes where they were given water and food ad libitum until the date scheduled for hepatectomy. This method leads to hypertension as described in a previous study ${ }^{13}$. A week later, under new anesthesia, a new laparotomy was followed by partial hepatectomy, resection of the left lateral and median lobes. This hepatectomy is equivalent to a resection of approximately $67 \%$ of the volume of viscera ${ }^{14}$. The resected segments were weighed and recorded in a protocol. The measurements were taken after 24 hours and again after seven days, when 10 animals in each group were euthanized. Thus subgroups C1, C2, E1 and E2 were obtained. The rats were weighed again before the autopsy, and then a new laparotomy was performed with total resection of the liver which was weighed and the value recorded in a protocol.

To measure the mass gain, the Kwon et al. ${ }^{15}$ formula was used: \% Regeneration = D / E .100, where E = R / 0.7; where: D= weight of liver per $100 \mathrm{~g}$ of animal weight on the day of euthanasia, $\mathrm{E}=$ the estimated weight per $100 \mathrm{~g}$ of animal weight, before hepatectomy, which is calculated by the weight of the resected liver (R).

The resected livers were set in $10 \%$ formalin and sent for histopathology. From the blocks, four-to-five-micrometer cuts were obtained. Since the liver stellate cells (HSC) express the a-smooth muscle actin ${ }^{16}$, sections were prepared and incubated with the monoclonal anti-smooth muscle actin, (the SM-actin ${ }^{\circledR}$, DAKO A/S, Denmark) in BSA 1:400 concentration, followed by biotinylated anti-mouse immunoglobulin and avidin-biotin- 
peroxidase. The substrate diaminobenzidine was used as a chromogen. The stellate cells labeled for smooth muscle actin were counted in 10 microscopic fields adjacent to the portal spaces (periportal, zone 1 of Rappaport's liver acinus) and 10 microscopic fields adjacent to the centrilobular veins (pericentral region, zone 3 of the acinus Rappaport). The sections were examined in randomly selected microscopic fields, increased by 400 times. In this increase, the periportal and pericentral regions are adjacent and representative of the entire liver lobule.

Other sections were incubated with monoclonal antibody Ki67, which labels proliferating cells. The inactive hepatocytes were counted in 10 microscopic fields adjacent to the portal spaces. The sections were also examined in randomly selected microscopic fields, an increase of 400 times.

The count of stellate cells was subjected to statistical analysis by Fisher's test and Student's t test, at two different times. Data regarding the counting of hepatocytes labeled with Ki67 were statistically analyzed by applying Fisher's test at two different times. The significance level was established at $5 \%(\mathrm{p}<0.05)$.

\section{Results}

One animal from the control group and one from the experiment died after the first laparotomy, two more from the control group and one from the experiment group died immediately after hepatectomy, and two from the experimental group died during the second laparotomy. Thus, 17 animals from the control group and 16 from the experiment group were analyzed.

The different groups (C1, C2, E1, E2) were compared for a liver mass gain using Student's t test. Initially C1 and E1 were compared, corresponding to animals undergoing evaluation and euthanasia in 24 hours after partial hepatectomy. In this case, the t-test with non-homogeneous variances was more appropriate in the data analysis. Both tests showed no significance $(\mathrm{p}=0.4369)$ for these groups of animals. In groups C2 and E2, which corresponded to the animals euthanized seven days after partial hepatectomy, we observed that the animals in the control group (C2) had a higher liver mass gain than the experimental group (E2) $(p=0.0051)$ (Figure 1).

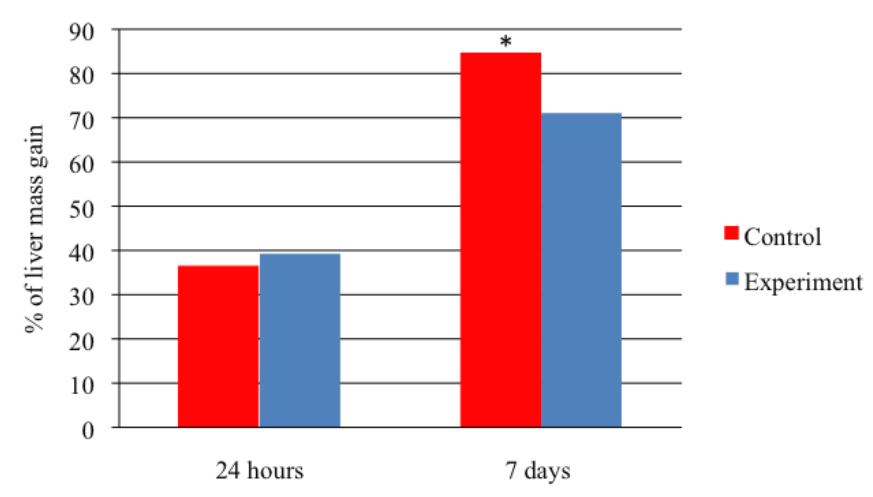

FIGURE 1 - Porcentage of liver mass gain following partial hepatectomy $(* \mathrm{*}<0.05)$.

There was no significant difference in the stellate cell counts after 24 hours $(p=0.4366)$ and seven days $(p=1.0)$ (Table 1 and Figure 2).

TABLE 1 - Descriptive analysis of stellate cells.

\begin{tabular}{c|c}
\hline Description & Number of stellate cells labeled with $\alpha$ AML \\
\hline A & $0-25$ \\
B & $26-50$ \\
C & $51-75$ \\
D & $76-100$ \\
E & $>100$ \\
\hline
\end{tabular}
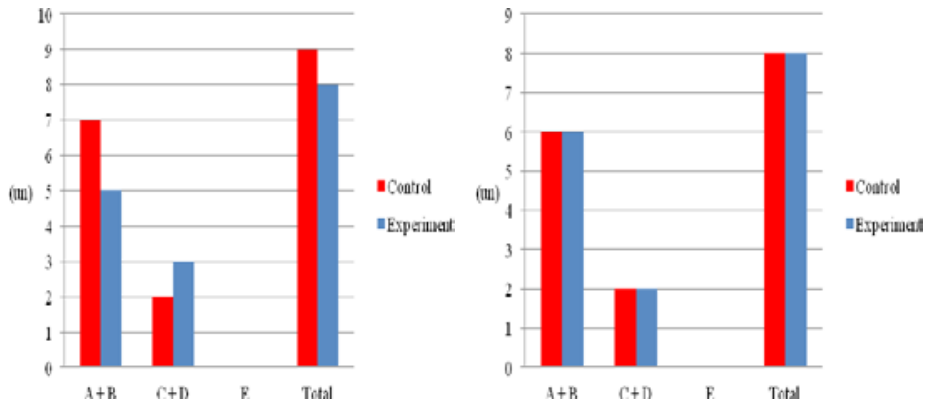

FIGURE 2 - A) Number of observations by number of stellate cells labeled with $\alpha$ AML within 24 hours after partial hepatectomy. B) Number of observations by number of stellate cells labeled with $\alpha \mathrm{AML}$ in the seven days following partial hepatectomy.

In relation to the counting of hepatocytes labeled with Ki67, there was no significant difference between the groups after 24 hours ( $\mathrm{C} 1$ and $\mathrm{E} 1, \mathrm{p}=1.0)$. In the groups evaluated seven days after partial hepatectomy, a greater number of cells labeled with Ki67 was observed in the control group $(p=0.0014)$ (Table 2 and Figure 3). 
TABLE 2 - Analysis of hepatocyte counts.

\begin{tabular}{c|c}
\hline Description & Number of hepatocytes labeled with Ki67 \\
\hline F & $150-175$ \\
G & $176-200$ \\
H & $>200$ \\
\hline
\end{tabular}

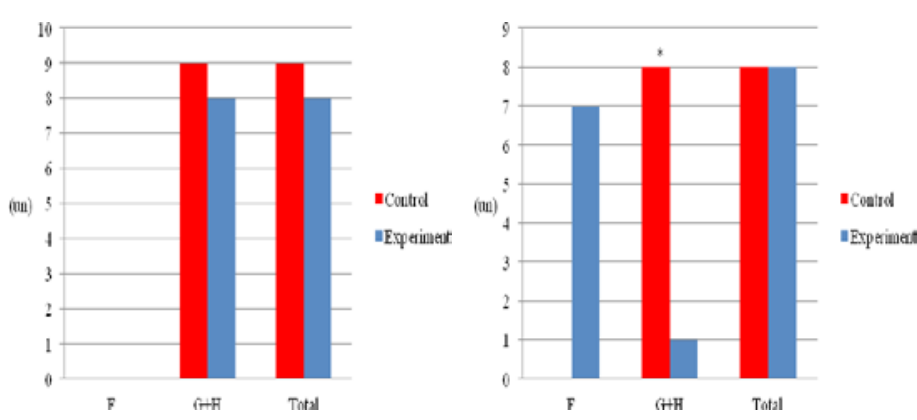

FIGURE 3 - A) Number of observations by number of hepatocytes labeled with Ki67 in 24 hours after partial hepatectomy. B) Number of observations by number of hepatocytes labeled with Ki67 within seven days of partial hepatectomy $\left({ }^{*} \mathrm{p}<0.05\right)$.

\section{Discussion}

It was observed that the animals with induced renovascular hypertension had impaired liver regeneration. The gain in liver mass and replication of hepatocytes were higher in the control group compared to the experimental group, after seven days of partial hepatectomy but not after 24 hours of intervention. These observations are in agreement with Ramalho et al. ${ }^{11}$ and Yayama et al. ${ }^{12}$ who showed that, although the mechanisms were unknown, the ACE inhibits liver regeneration. The results of this study may suggest, as did Ramalho et al. ${ }^{11}$, that the use of blockers of ACE would be capable of promoting liver regeneration. The fact that hypertension altered hepatic regeneration only later in the study can be explained by Koh et al. ${ }^{17}$, who, when analyzing the sequence in which the structures are formed during regeneration, observed that the hepatic microvasculature is formed at a later time. This observation suggests the possibility that hypertension influences the later processes of liver regeneration.

According Masuko et al., cited by Bahde et al. ${ }^{18}$, angiotensin-2 acts through the AT1 receptor, mediating vasoconstriction and cell proliferation, and through AT2 receptors involved in antiproliferative activity, cell differentiation and apoptosis. Stimulation of the AT2 receptor by blocking the AT1 receptor may contribute to the effects on the proliferation of hepatocytes. However, according to Bru-Sancho et al. and Patel et al., cited by Bahde et al. ${ }^{18}$, inhibitors of angiotensin converting enzyme may be more favorable in relation to antifibrotic therapy due to liver regeneration, and preventing the simultaneous production of angiotensin-2, degradation of bradykinin and induction of production of angiotensin 1-7. Although the change in the replication of stellate cells was not observed in our study, the authors suggest that angiotensin-2, involved in the pathogenesis of hypertension, can increase the activity of stellate cells, leading to a stimulus for the replication of hepatocytes with consequent stimulation of liver regeneration.

In the process of liver regeneration, hepatic stellate cells proliferate, reaching a peak 48 hours after partial hepatectomy. As a result, the relationship between stellate cells and endothelial cells is at its greatest 72 hours after partial hepatectomy, allowing greater interaction between these two cell types in a critical period of neovascularization during regeneration after partial hepatectomy. It is likely that this relationship can facilitate the process of vascularization through the exchange of growth factors, the matrix and chemotaxis ${ }^{5}$. Mabuchi et al. ${ }^{7}$ also confirmed that the relationship between stellate cells and hepatocytes is altered due to the regenerative process. Using intravital fluorescence microscopy, the researchers observed that islands of activated stellate cells (expressing-smooth muscle actin) were in close association with hepatocytes, indicating that the activation of those and the interaction with these may have been related to events during regeneration. The use of transgenic models has produced information on how the abnormal function of hepatic stellate cells results in defects in regeneration. Kalinichenko et al. ${ }^{19}$ showed that haploinsufficiency of the gene transcription factor Foxf1 expressed in the liver stellate cells in adult and developing livers, results in impaired regeneration (after injury $\mathrm{CCl} 4$ ) in spite of normal cell proliferation, probably due to increased apoptosis. Moreover, Issa et al..$^{20}$ demonstrated that the persistent activation of stellate cells in animals subjected to a lesion with CCl4 was followed by inability to regenerate appropriately. Inhibition of proliferation of hepatocytes may represent an important mechanism in the nonrestoring function of the liver. These two examples suggest that the deficiency and uncontrolled activation of stellate cells impair liver regeneration. Thus a finely tuned response of these cells can be an important factor to ensure adequate regeneration ${ }^{9}$.

According to Moreno et al., cited by Bahde et al. ${ }^{18}$, angiotensin-2 acting through angiotensin-1 (AT1) receptors in stellate cells (via the renin-angiotensin system) has been shown to be an important mediator of liver fibrosis by increasing the proliferation of stellate cells, the synthesis of growth factors, cytokines and other bioactive molecules. Increasing evidence shows that the blockade of AT1 receptors may reduce the accumulation of activated stellate cells and attenuate liver fibrosis, 
as described in the study by Kim et al., cited by Bahde et al. ${ }^{18}$. However, since stellate cells are the main source of hepatocyte hepatic growth factor, an AT1 receptor blockade may affect the regenerative response of the liver ${ }^{21}$. Little is known about the impact of AT1 receptor blockade on liver regeneration, and recent studies show contradictory results, probably due to different experimental conditions ${ }^{18}$. In an experiment conducted by Bahde et $a l .{ }^{18}$ in cirrhotic rats, losartan (AT1 receptor inhibitor) had a significant inhibitory effect on the activation of stellate cells despite hyperperfusion of the liver, which may have affected the regenerative response of hepatocytes to partial hepatectomy. At the end of the experiment, the authors observed that the number of proliferating hepatocytes was higher in animals treated with the drug, indicating that regeneration of hepatocytes was delayed or prolonged. These results are in agreement with studies by Ramalho et al. ${ }^{11}$ demonstrating that losartan $5 \mathrm{mg} / \mathrm{kg}$ decreases proliferative activity after partial hepatectomy. These findings indicate that AT1 receptor blockade may increase the hepatic blood flow and reduce collagen deposition, but may exacerbate apoptosis and interfere with the proliferation of hepatocytes after liver resection in cirrhotic livers ${ }^{18}$.

\section{Conclusion}

The renovascular hypertension in this experiment did not influence stellate cells, but led to a delay in liver mass gain seven days after partial hepatectomy and proved to be a factor that reduced the replication of hepatocytes, not earlier, but later.

\section{References}

1. Cruise JL, Cotecchia S, Michalopoulos GK. Norepinephrine decreases EGF binding in primary rat hepatocyte cultures. J Cell Physiol. 1986;127(1):39-44.

2. Marti U, Burwen SJ, Jones AL. Biological effects of epidermal growth factor with emphasis on the gastrointestinal tract and liver. Hepatology. 1989;9(1):126-38.

3. Fladmark KE, Gjertsen BT, Molven A, Mellgren G, Vintermyr OK, Doskeland SO. Gap junctions and growth control in liver regeneration and in isolated rat hepatocytes. Hepatology. 1997;25(4):847-55.

4. Friedman SL. Hepatic stellate cells: protean, multifunctional, and enigmatic cells of the liver. Physiol Rev. 2008;88(1):125-72.

5. Balabaud C, Bioulac-Sage $P$, Desmoulière A. The role of hepatic stellate cells in liver regeneration. J Hepatol. 2004;40(6):1023-26.

6. Vogten JM, Smakman N, Voest EE, Borel Rinkes IH. Intravital analysis of microcirculation in the regenerating mouse liver. J Surg Res. 2003;113(2):264-69.

7. Mabuchi A, Mullaney I, Sheard PW, Hessian PA, Mallard BL, Tawadrous MN, Zimmermann A, Senoo H, Wheatey AM. Role of hepatic stellate cell/hepatocyte interaction and activation of hepatic stellate cells in the early phase of liver regeneration in the rat. $\mathrm{J}$ Hepatol. 2004;40(6):910-6.
8. Wack KE, Ross MA, Zegarra V, Sysko LR, Watkins SC, Stolz DB. Sinusoidal ultrastructure evaluated during the revascularization of regenerating rat liver. Hepatoly. 2001;33(2):363-78.

9. Xu C, Chen X, Chang C, Wang G, Wang W, Zhang L, Zhu Q, Wang L, Zhang F. Analysis of gene expression profiles of liver stellate cells during liver regeneration in rats. Mol Cells. 2011;31(1):17-23.

10. Biondo-Simões MLP, Pante M, Garcia RF, de Macedo VL, de Morais THC, Boell P. Hormônio de crescimento na regeneração hepática em ratos. Rev Col Bras Cir. 2000;27(2):114-7.

11. Ramalho FS, Ramalho LN, Castro e Silva Júnior O, Zucoloto S, Corrêa FM. Effect of angiotensin-converting enzyme inhibitors on liver regeneration in rats. Hepatogastroenterology. 2002;49(47):1347-51.

12. Yayama K, Sugiyama K, Miyagi R, Okamoto H. Angiotensinconverting enzyme inhibitor enhances liver regeneration following partial hepatectomy: involvement of bradykinin B2 and angiotensin AT1 receptors. Biol Pharm Bull. 2007;30(3):591-4.

13. Biondo-Simões MLP, Zazula AD, Gomes AB, Poncio C, Torres LFB, Borsato KS. Influence of arterial hypertension treated with losartan on skin healing in rats. Acta Cir Bras. 2006;21(3):144-50.

14. Higgins GM, Anderson RM. Experimental pathology of the liver: I. Restoration of the liver of the white rat following partial surgical removal. Arch Pathol. 1931;12:186-202.

15. Kwon AH, Uetsuji S, Yamamura M, K Hioki, Yamamoto M. Effect of administration of fibronectin or aprotinin on liver regeneration after experimental hepatectomy. Ann Surg. 1990;211(3):295-300.

16. Sanz S, Pucilowska JB, Liu S, Rodríguez-Ortigosa CM, Lund PK, Brenner DA, Fuller CR, Simmons JG, Pardo A, Martinez-Chantar ML, Fagin JÁ, Prieto J. Expression of insulin-like growth factor I by activated hepatic stellate cells reduces fibrogenesis and enhances regeneration after liver injury. Gut. 2005;54(1):134-41.

17. Koh SL, Ager EI, Christophi C. Liver regeneration and tumour stimulation: implications of the renin-angiotensin system. Liver Int. 2010;30(10):1414-26.

18. Bahde R, Kebschull L, Stoppeler S, Zibert A, Siaj R, Holzen JP, Minin E, Schmidt HH, Spiegel HU, Palmes D. Role ofangiotensin1receptor blockade in cirrhotic liver resection. Liver Int. 2011;31(5):642-55.

19. Kalinichenko VV, Bhattacharyya D, Zhou Y, Gusarova GA, Kim W, Shin B, Costa RH. Foxf1 b /2 mice exhibit defective stellate cell C activation and abnormal liver regeneration following CCl4 injury. Hepatology. 2003;37(1):107-17.

20. Issa R, Zhou X, Trim N, Millward-Sadler H, Krane S, Benyon C, Iredale J. Mutation in collagen- 1 that confers resistance to the action of collagenase results in failure of recovery from CCl4-induced liver fibrosis, persistence of activated hepatic stellate cells, and diminished hepatocyte regeneration. FASEB J. 2003;17(1):47-9.

21. Ramalho LN, Zucoloto S, Ramalho FS, Castro-e-Silva O Jr, Corrêa FM. Effect of antihypertensive agents on stellate cells during liver regeneration in rats. Arq Gastroenterol. 2003;40(1):40-4.

\section{Correspondence:}

Maria de Lourdes Pessole Biondo-Simões

Rua Ari José Valle, 1987

82030-000 Curitiba - PR Brasil

Tel.; (55 41)3297-4359/3223-4637/9991-5566

malubiondo@gmail.com

Received: February 15, 2012

Review: April 12, 2012

Accepted: May 14, 2012

Conflict of interest: none

Financial source: none

${ }^{1}$ Research performed at Division of Surgical Technique and Experimental Surgery, Federal University of Parana (UFPR), Brazil. 